
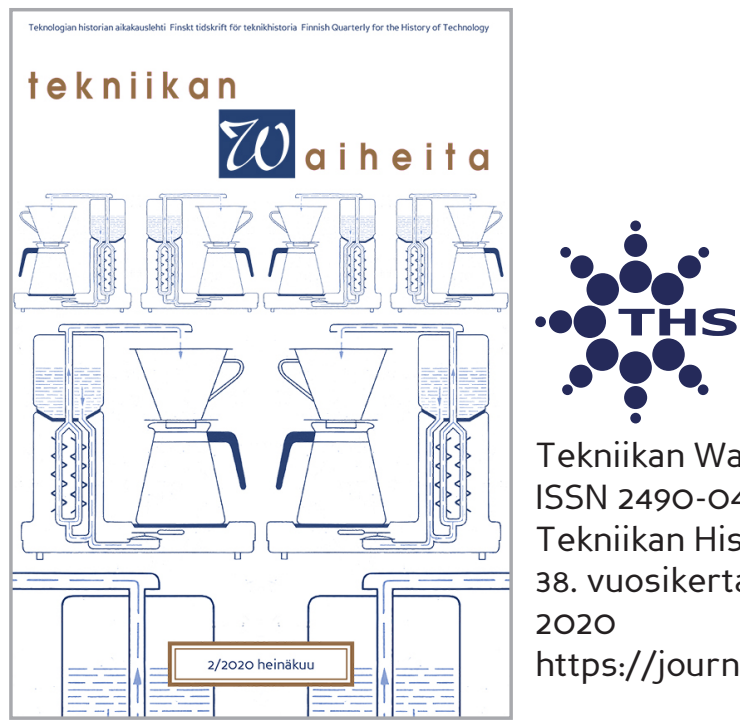

Tekniikan Waiheita

ISSN 2490-0443

Tekniikan Historian Seura ry.

38. vuosikerta:2

2020

https://journal.fi/tekniikanwaiheita

\title{
Puukaasulla köröteltiin
}

Veijo Kauppinen

To cite this article: Veijo Kauppinen, "Puukaasulla köröteltiin" Tekniikan Waiheita 38, no. 2 (2020): 34-37. https://dx.doi.org/10.33355/tw.96987

To link to this article: https:/ /dx.doi.org/10.33355/tw.96987 


\title{
Puukaasulla köröteltiin
}

\author{
Veijo Kauppinen'
}

Sotien välissä syntynyt kirjoittaja muistaa hyvin kotia lähellä sijainneen linjuriaseman kuskien puuhailut häkäpönttöjensä kanssa ja kuuli sivusta heidän keskustelujaan. Pilkkeiden sytyttämiseen käytettyjä erikoistikkujakin heltisi joskus nuorison kyseenalaisiin leikkeihin.

Ajoneuvojen puukaasutekniikan taustalla olivat saksalaisen ja ranskalaisen metalliteollisuuden masuunikaasulla käytetyt valtavankokoiset teollisuusmoottorit. Sekä antrasiittihiilen kaasutustekniikalla kulkevia kulkuneuvoja että sähköautoja oli nähty jo 1800-luvulla. Erityisesti Saksassa kehitettiin ruskohiiltä, puujätettä tai turvetta polttavia laitteistoja, mutta tekniikkaa hyödynnettiin myös Ranskassa ja Englannissa. Alan valmistajia olivat Renault, Imbert ja Berliot. Auton mukana kulkevat kaasuttimet liitettiin aluksi linja- ja kuorma-autoihin, myöhemmin myös kookkaisiin henkilöautoihin.

Suomessa huolestuttiin mahdollisen kriisin aikaisesta polttoainehuollosta ja päätettiin tutkia pontevasti kotimaisen nestemäisen polttoaineen valmistamista. Kemian professori Gustaf Komppa tutki synteettisen bensiinin valmistamista kotimaisesta rakka-aineesta. Synteettinen bensiini ei tullut laajasti käyttöön, mutta erityisesti 1940-luvulla juna ja vesiliikenteen rinnalle tarvittavaa, kumipyörin tapahtuvaa henkilö- ja tavaraliikennettä jouduttiin polttoaineen puuttuessa hoitamaan paljolti puukaasukäyttöisesti.

Häkäpönttöautossa pönttöön ladatut pilkkeet kaasutetaan hapettomassa tilassa. Puuhiili palaa ensin hiilikaasuttimessa hiilidioksidiksi $\mathrm{C}+\mathrm{O} 2 \rightarrow \mathrm{CO} 2$ ja sen jälkeen kosketuksessa hehkuviin hiliiin hiilimonoksidiksi CO2 $+\mathrm{C} \rightarrow 2 \mathrm{CO}$.

Työturvallisuus oli huomioitava, onhan häkä vaarallinen, myrkyllinen kaasu. Puupilkkeitä käytettäessä kaasun koostumus on noin $24 \%$ hiilimonoksidia, $18 \%$ vetyä, $4 \%$ metaania ja loput palamattomia aineita.

Tom Rönnbergin artikkeli Linja-autohistoriallisen seuran jäsenlehdessä Hetkussa (1/2020) kertoo kuinka jo opiskelijana eteväksi osoittautunut kemisti ja koneenrakentaja Harald "Kylle" Kyrklund (1881-1965) nimitettiin vuonna 1917 Suomen Teknillisen Korkeakoulun professoriksi ja lämpövoimalaboratorion johtajaksi. Rönnberg toteaa hänen Puolustusvoimille 1920- ja 1930-luvuilla tilaustyönä tekemänsä tutkimustyön nostaneen maamme puun kaasutustekniikan eturintamaan. Suomen Filmiteollisuus SF jopa teki vuonna 1938

\footnotetext{
${ }^{1}$ Kirjoittaja on konepajatekniikan emeritusprofessori.
} 


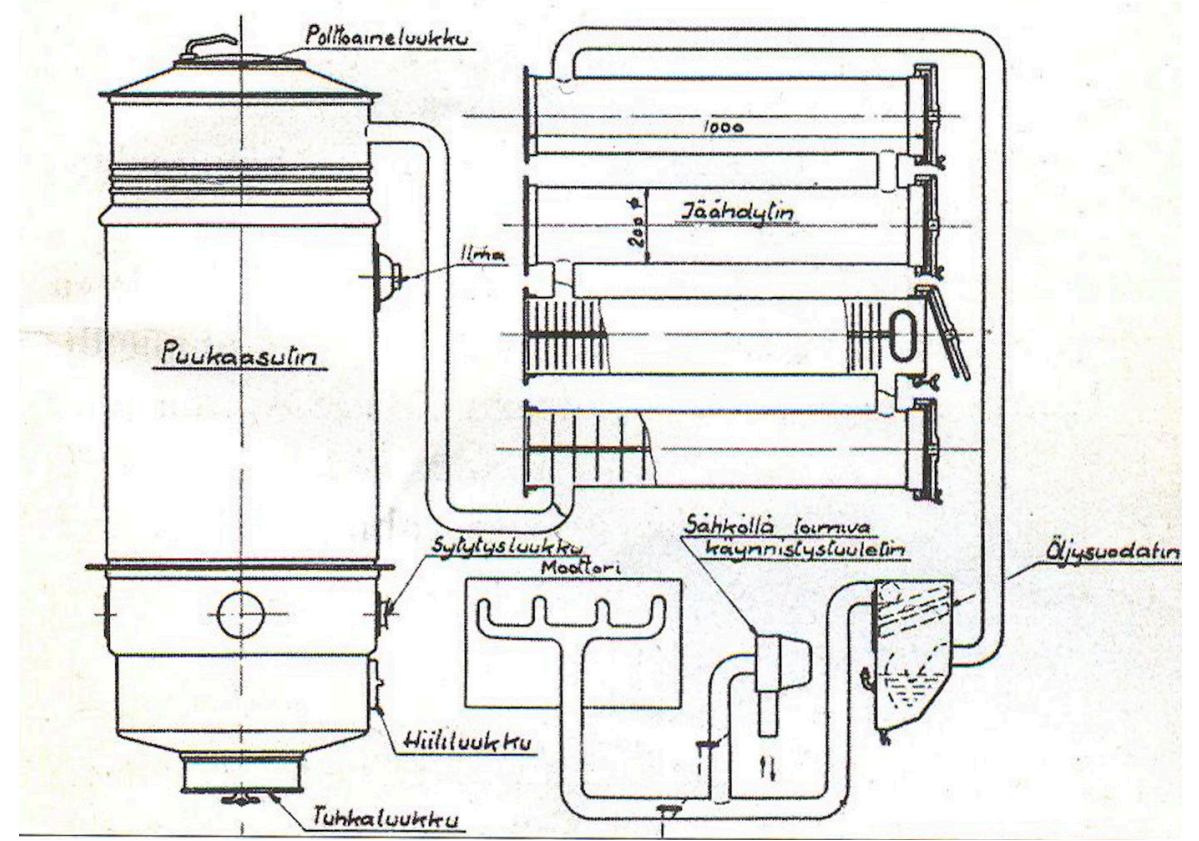

Kuva 2. Otso-puukaasuttimen periaatepiirros. Kuva: Linja-auto- ja koriteollisuusmuseo Lavia.

lyhytelokuvan tutkimuksessa käytetystä Fargo-kuorma-autosta. Häkäkaasututkimuksia tehtiin TKK:n autolaboratoriossa M-B dieselmoottoreilla edelleen ainakin 1970-luvulle saakka.

Suomeen hankittiin syksyllä 1928 kaksi puukaasutinkuorma-autoa, toinen Paraisten Oy:lle ja toinen Puolustusministeriölle. Suomi lienee ollut ensimmäinen puukaasuttimia kaupalliseen käyttöön valmistanut pohjoiseurooppalainen maa, kun Hietalahden Sulkutelakka ja Konepaja rakensivat muutamia koekappaleita 1920-luvun lopulla.

Useat konepajamme alkoivat valmistaa puukaasuttimia, joiden valmistuksen kokonaismääräksi arvioidaan noin 43 000. Korroosio syövytti laitteita, joita oli myös uusittava. Lisäksi Volvo-Auto myi Suomeen vuosina 1941-1946 reilut tuhat puupilkekaasutinta. Niitä valmistanut Wärtsilä neuvotteli vuonna 1942 Volvon kanssa kuorma-autotehtaan perustamisesta Suomeen, mutta hanke kaatui Ruotsia vaivanneeseen materiaalipulaan.

Puukaasulla käyviä autoja verotettiin vuodesta 1931 lähtien syksyyn 1939 saakka. Hiilikaasutuslaitteet kiellettiin vuonna 1942, minkä jälkeen autoissa käytettiin pelkästään pilkettä. Kuljettajan piti sytyttää ilmakuivaa lehtipuuta olevat, nyrkin kokoiset pilkkeet reilusti ennen lähtöä ja puhdistaa pönttö ajon jälkeen.

Ahtamattoman kaasumoottorin teho oli noin kolmanneksen öljyperäisiä polttoaineita huonompi. Hyötysuhdetta parantava kompressori ei yleistynyt siinä esiintyneiden ongelmien takia. Matkustajat saatettiin mäkien alla komentaa ulos autoa työntämään.

Muista kriisiaikojen vaihtoehtoisista polttoaineista on mainittava myös metaani, jota eräät jäteveden puhdistuslaitokset tuottivat vuonna 1941. Pullotettuun kaasuun perustuva menetelmä oli kuitenkin painavien pullojen takia liian raskas tullakseen laajempaa käyttöön. 
Panu Nykänen on tutkimustensa perusteella argumentoinut, että sodan pula-ajan pahin puute ei ollut polttoaine, vaan moninaisten koneiden ja moottoreiden tarvitsema, riittävän laadukas voiteluöljy.

Pöntöt poistuivat liikenteestämme bensiinin säännöstelyn päätyttyä vuonna 1949. Kaasua voi toki nykyisin autoonsa tankata. Harrastelijat, kuten Suomen Ekoautoilijat ry:n jäsenet, rakentavat edelleen puukaasutuslaitteistoja. Pääministeri Juha Sipilän rakentama, vuoden 1987 El Camino eli El Kamina kulkee koivupilkkeellä. Metsäalan nykyisten asiantuntijoiden yleinen käsitys kuitenkin on, ettei sota-ajan kuljetukset pelastaneesta tekniikasta enää olisi uuden kriisitilanteen ratkaisijaksi.

\section{Lähteet}

Rönnberg, Tom. 2020. "Puukaasu polttoaineena". Suomen Linja-autohistoriallisen Seuran jäsenlehti Hetku 1: 24-27.

Nykänen, Panu. 1999. Bensiinihiilivetyjen valtiaat, voitelu ja moottoripolttoaineiden tutkimus Suomessa vuoteen 1948. Diss. Helsingin yliopisto.

Nykänen, Panu. 2007. Kortteli sataman laidalla, Suomen Teknillinen Korkeakoulu 1908-1941. Helsinki: WSOY.

Nykänen, Panu. 2019. Kun hevosvoimat syrjäyttivät hevosen. Autoalan koulutuksen tarve, synty ja vakiintuminen. Vuodet 1900-1970. Helsinki: Suomen Autoteknillinen Liitto ry. 